\title{
PENGARUH SENAM BUGAR LANSIA TERHADAP KADAR TRIGLISERIDA
}

\author{
${ }^{1}$ Ronald Sondakh \\ ${ }^{2}$ Damajanty Pangemanan \\ ${ }^{2}$ Sylvia Marunduh
}

\author{
${ }^{1}$ Kandidat Skripsi Fakultas Kedokteran Universitas Sam Ratulangi Manado \\ ${ }^{2}$ Bagian Fisiologi Fakultas Kedokteran Universitas Sam Ratulangi Manado \\ Email: onaldsondakh@yahoo.com
}

\begin{abstract}
Triglycerides are one of fat body. Elevated levels of triglycerides occur because of obesity, alcohol consumption, sugar, and lack of activity, induced accumulation of triglycerides in the blood. Elderly is individuals with a restriction of physical activity due to physical conditions or disallowance of the family. This restriction leads to reduced physical activity that very useful for lowering triglycerides level. This causes an increase triglyceride levels. This study aims to look at the influence of elderly aerobics exercise on triglyceride levels. This research was an experimental design of the field with pre-post one group test. Samples were 30 elderly that lived in BPLU Senja Cerah, Paniki Bawah. Samples fasting for 8 hours to blood sampling. Tests performed are elderly aerobics exercise performed for 30 minutes in a $3 \mathrm{x}$ a week for 3 weeks. The results analyze with paired sample t-test to determine the differenc e in the results triglyceride levels before and after exercise. The obtained results showed a highly significant difference between triglycerides levels before and after exercise with $\alpha=0,004(<0,05)$ as shown by $t_{\text {hitung }}(3.153)>\mathrm{T}_{\text {tabel }}(2.045)$ Elderly aerobics exercise showed a significant effect in reducing trigiyceride levels in the blood.
\end{abstract}

Keyword: elderly aerobics exercise, triglycerides, elderly.

\begin{abstract}
Abstrak: Trigliserida merupakan salah satu lemak didalam tubuh. Peningkatan kadar trigliserida terjadi karena kegemukan, konsumsi alkohol, gula, serta kurangnya aktivitas sehingga menyebabkan penumpukan trigliserida dalam darah. Lansia merupakan individu yang mengalami pembatasan aktivitas fisik dikarenakan kondisi fisik atau larangan dari keluarga. Pembatasan ini menyebabkan berkurangnya aktivitas fisik yang berguna untuk menurunkan kadar trigliserida dalam darah. Hal ini menyebabkan peningkatan kadar trigliserida dalam darah. Penelitian ini bertujuan untuk melihat pengaruh senam bugar lansia terhadap kadar trigliserida. Penelitian ini bersifat ekperimental lapangan dengan rancangan pre-post one group test. Sampel berjumlah 30 orang yang merupakan Lansia yang berada di BPLU Senja Cerah, Paniki Bawah. Sampel berpuasa selama 10 jam sebelum dilakukan pengambilan darah. Tes yang dilakukan adalah senam bugar lansia yang dilakukan selama 30 menit dalam 3x seminggu selama 3 minggu. Hasil yang didapatkan diolah dengan uji $t$ berpasangan untuk melihat perbedaan hasil kadar trigliserida sebelum melakukan senam dan setelah melakukan senam. Hasil yang didapatkan menunjukkan perbedaan yang sangat signifikan antara kadar trigliserida lansia sebelum senam dan sesudah senam dengan $\alpha=$ $0,004(<0,05 \%)$ hal ini ditunjukkan dengan $t_{\text {hitung }}(3,153)>t_{\text {tabel }}(2,045)$. Senam bugar lansia memberikan pengaruh yang sangat signifikan dalam menurunkan kadar trigliserida dalam darah.
\end{abstract}

Kata Kunci: aktivitas fisik, senam bugar, trigliserida, lansia. 
Penuaan (aging) adalah suatu proses menghilangnya secara perlahan-lahan kemampuan jaringan untuk memperbaiki diri atau mengganti diri dan mempertahankan struktur dan fungsi normalnya, sehingga tidak dapat bertahan terhadap jejas (termasuk infeksi) dan memperbaiki kerusakan yang diderita. ${ }^{1}$ Lanjut usia menurut UU RI no 13 tahun 1998 adalah mereka yang telah memasuki usia 60 tahun ke atas. Banyak istilah yang dikenal masyarakat untuk menyebut orang lanjut usia, antara lain lansia singkatan dari lanjut usia. Istilah lain adalah manula merupakan singkatan dari manusia lanjut usia. ${ }^{2}$

Pandangan sebagian masyarakat yang menganggap lansia sebagai manusia yang tidak mampu, lemah, dan sakit-sakitan menyebabkan mereka memperlakukan lansia sebagai manusia yang tidak berdaya, sehingga segala aktivitas sangat dibatasi. Kondisi ini diperparah oleh tidak adanya waktu, tempat, dan kesempatan bagi lansia dalam melakukan aktivitas untuk mengisi sisa hidupnya. ${ }^{3}$

Pertumbuhan penduduk lanjut usia (lansia) meningkat secara cepat pada abad 21 ini. Pada tahun 2000 jumlah lansia di dunia telah mencapai 425 juta jiwa $( \pm 6,8$ persen). Indonesia merupakan negara urutan ke-4 dengan jumlah lansia paling banyak sesudah Cina, India dan Amerika Serikat terdapat 15.262.199 atau 7,28\% dari total populasi. Jumlah ini diperkirakan akan mengalami peningkatan hampir dua kali lipat pada tahun 2025. Pada tahun 2005 jumlah lansia menjadi 17.767.709 atau 7,97\%. ${ }^{4}$ Berdasarkan data Badan Statistik Indonesia pada tahun 2012, jumlah lansia yang ada di Sulawesi Utara adalah 174.077 orang dengan rincian laki-laki 87.036 orang dan perempuan 87.041 orang. Lansia di Kota Manado berjumlah 20.391 orang dengan rincian lansia laki-laki sebanyak 8.624 orang dan lansia perempuan sebanyak 11.767 orang.

Trigliserida merupakan lemak utama di dalam tubuh, dibentuk di hati dari gliserol dan lemak yang berasal dari makanan atau dari kelebihan kalori akibat makan berlebihan. Hampir seluruh trigliserida terutama yang bersifat jenuh dapat diserap oleh tubuh, sehingga mengkonsumsi makanan yang mengandung lemak jenuh tinggi memberikan kontribusi besar dalam meningkatkan kadar trigliserida dalam darah. ${ }^{5}$

Latihan atau exercise sangat penting untuk menghindari perubahan yang tibatiba dan gaya hidup aktif kegaya hidup sederhana. Kaum lansia akan mengalami stres karena perubahan secara drastis dan kesedihan yang sangat, serta merasa minder dari akibat perubahan pola hidup tersebut. ${ }^{3}$

Kebugaran jasmani sangat diperlukan untuk mencegah atau menunda penyakitpenyakit degeneratif dan penyakit kelainan metabolisme. Penyakit degeneratif adalah penyakit yang muncul setelah seseorang mengalami proses penuaan. Penyakit karena kelainan metabolisme adalah penyakit yang berhubungan dengan proses pembuatan energi, seperti diabetes melitus dan hiperlipidemia. ${ }^{6}$

Salah satu jenis latihan kebugaran jasmani untuk lansia adalah senam. Senam lansia adalah olahraga ringan dan mudah dilakukan, tidak memberatkan untuk diterapkan pada lansia. Aktivitas olahraga ini akan membantu tubuh agar tetap bugar dan tetap segar, melatih tulang tetap kuat, mendorong jantung bekerja optimal dan membantu menghilangkan radikal bebas yang berkeliaran di dalam tubuh. ${ }^{7}$

\section{METOLOGI PENELITIAN}

Penelitian bersifat eksperimental lapangan dengan rancangan pre-post one group test. Subjek merupakan lansia Badan Penyantunan Lanjut Usia (BPLU) Senja Cerah Manado dengan kriteria berusia $\geq 60$ tahun, sehat saat akan diperiksa, bersedia menjadi responden, sehat saat dilakukan penelitian. Penelitian dilakukan selama bulan November-Desember 2012. Pengambilan darah dilakukan sebelum dan sesudah diberikan perlakuan. Subjek berjumlah 30 orang dan diberikan perlakuan berupa senam bugar lansia secara rutin 3 kali dalam 1 minggu selama 3 minggu. Hasil penelitian diuji dengan 
paired sample t-test yang digunakan untuk menentukan pengaruh senam bugar lansia terhadap kadar kolesterol, sebelum dan sesudah perlakuan dengan $\alpha=0,05$.

\section{HASIL PENELITIAN}

Pada penelitian ini dari jumlah 30 orang lansia yang menjadi subjek penelitian, sebanyak 17 lansia (56,7\%) berumur 60-74 tahun sedangkan sisanya sebanyak 13 orang lansia (43,3\%) berumur 75-89 tahun. Dari tabel tersebut dapat dilihat bahwa subjek penelitian dari penelitian ini dominan berumur 60-74 tahun.

Tabel 1. Klasifikasi berdasarkan umur subjek penelitian

\begin{tabular}{ccc}
\hline Umur & Jumlah & Presentase \\
\hline $\begin{array}{c}\text { Elderly (60- } \\
74 \text { tahun) }\end{array}$ & 17 & $56,7 \%$ \\
\hline $\begin{array}{c}\text { Old (75-89 } \\
\text { tahun) }\end{array}$ & 13 & $43,3 \%$ \\
\hline
\end{tabular}

Pada tabel 2 akan diuraikan mengenai jenis kelamin dari lansia yang menjadi subjek penelitian ini, yaitu:

Tabel 2. Klasifikasi berdasarkan jenis kelamin

\begin{tabular}{ccc}
\hline $\begin{array}{c}\text { Jenis } \\
\text { Kelamin }\end{array}$ & Jumlah & Presentase \\
\hline Laki-laki & 10 & $33,3 \%$ \\
\hline Perempuan & 20 & $66,7 \%$ \\
\hline
\end{tabular}

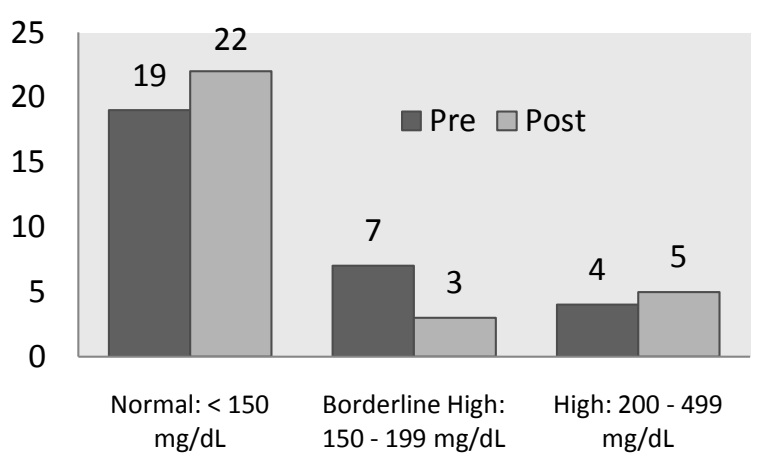

Gambar 1. Perbandingan trigiserida pre-post test.
Untuk jenis kelamin dari 30 orang subjek penelitian sebanyak 20 orang (66,7\%) merupakan wanita sedangkan 10 orang lansia $(33,3 \%)$ merupakan pria. Sehingga dapat disimpulkan bahwa lansia wanita yang paling banyak menjadi subjek penelitian dalam penelitian ini.

Dari gambar 1 dapat dilihat bahwa pada pengambilan darah pre-test didapati sebanyak 19 lansia (63,3\%) mempunyai kadar trigliserida berada dalam batas normal. 7 orang lansia $(23,3 \%)$ sudah memasuki borderline high, dan sebanyak 4 orang lansia $(13,3 \%)$ kadar trigliseridanya high. pada pengambilan darah post-test didapati sebanyak 22 lansia (73,3\%) yang kadar trigliserida berada dalam batas normal. Sedangkan sebanyak 3 orang lansia (10\%) sudah memasuki borderline high. Dan, sebnyak 5 orang lansia (16,7\%) kadar trigliseridanya high. Pada gambar 2 dapat dilihat bahwa terjadi perubahan pada pengukuran pre dan post test penelitian ini. Pada kadar normal trigliserida dari pengukuran pertama sebanyak 19 orang lansia yang mempunyai kadar trigliserida yang normal menjadi 22 orang lansia. Untuk kategori borderline high, berubah dari pre-test sebanyak 7 orang lansia menjadi 3 orang lansia pada waktu posttest. Sedangkan untuk kategori high, terjadi peningkatan dari pengukuran pre-test sebanyak 4 orang lansia yang termasuk kategori high menjadi 5 orang lansia. Hal ini menunjukkan terjadi penurunan kadar trigliserida sesudah melakukan senam.

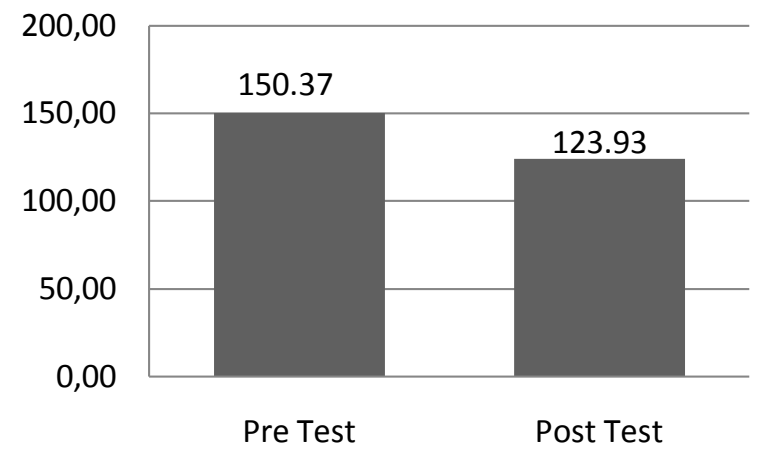

Gambar 2. Perbandingan trigiserida pre-post test. 
Dari gambar 2 dapat dilihat berdasarkan penelitian, rata-rata kadar trigliserida dalam darah sebelum melakukan senam bugar lansia adalah 150,37 mg/dL. Sedangkan rata-rata kadar trigliserida dalam darah sesudah latihan fisik adalah $123.93 \mathrm{mg} / \mathrm{dL}$.

\section{PEMBAHASAN}

Pada penelitian ini, trigliserida menjadi perhatian dari peneliti karena peneliti ingin membuktikan bahwa terdapat pengaruh senam bugar lansia terhadap kadar trigliserida. Dengan kisaran umur lansia yang menjadi subjek penelitian adalah 60-89 tahun.

Penelitian ini dianalisis menggunakan uji t berpasangan untuk melihat perbedaan kadar trigliserida lansia sebelum melakukan senam dan sesudah melakukan senam selama 30 menit selama seminggu dalam 3 minggu. Dari data yang diperoleh didapatkan perbedaan yang sangat signifikan antara kadar trigliserida lansia sebelum dan sesudah senam dengan konfidensi interval $95 \% \quad(\alpha<0,05)$ diperoleh nilai signifikan $0,004(<0,05)$. Hal ini didukung dengan beberapa penelitian sebelumnya yang menyatakan bahwa aktivitas fisik dapat menurunkan kadar trigliserida dalam darah.

Pada gambar 1 dapat dilihat terjadi peningkatan kadar trigliserida pada kategori high dari 4 orang menjadi 5 orang. Peningkatan ini dapat disebabkan oleh beberapa hal yaitu: tidak teraturnya subjek penelitian melakukan senam, tidak melakukan senam secara baik, tidak puasa selama 8 jam sebelum melakukan pengambilan darah, atau mengkonsumsi obat-obat yang dapat mempengaruhi kadar trigliserida

$$
\text { Penelitian Rantung } Y
$$

menunjukkan terjadi penurunan kadar trigliserida pada mahasiswa yang menjalani harvard test. Penurunan terjadi pada mahasiswa yang sering melakukan olahraga lalu melakukan tes sedangkan terjadi kenaikan kadar trigliserida pada mahasiswa yang tidak biasa melakukan olahraga lalu melakukan test. ${ }^{8}$
Hal yang sama dikemukakan oleh Krishna MM dan Gopinath V (2011), bahwa terjadi penurunan dari kadar trigliserida pada subjek penelitian percobaan setelah melakukan aktivitas fisik. Penurunan kadar trigliserida terjadi karena selama melakukan aktivitas fisik trigliserida dipakai dalam proses pembentukan energi dan pembakaran sel lemak dalam tubuh. $^{9}$

Widhalm (2004) yang menggunakan perbandingan kadar trigliserida sebelum dan sesudah diet dan berolahraga selama 3 minggu,mendapatkan adanya perbedaan yang sangat berarti antara kadar trigliserida sebelum dan sesudah berolahraga dan diet, dimana sesudah berolah raga dan diet kadar trigliserida menurun. ${ }^{10}$

\section{SIMPULAN}

Berdasarkan hasil penelitian dan pembahasan yang telah dijabarkan diatas dapat disimpulkan bahwa senam bugar lansia memberikan pengaruh yang sangat signifikan terhadap penurunan kadar trigliserida.

\section{UCAPAN TERIMA KASIH}

Ucapan terima kasih disampaikan kepada dr. J. N. A. Engka, M.Kes, AIFM, DK, dr. H. I. S. Wungouw, MsAppSc, MMedEd, AIFM, AIFO dan kepada semua pihak yang baik secara langsung maupun tidak langsung telah menumbuhkan ide/ gagasan dalam pemikiran penulis sehingga dapat menyelesaikan artikel ini.

\section{DAFTAR PUSTAKA}

1. Santosa H, Ismail A. Memahami krisis lanjut usia. Jakarta: BPK Gunung Mulia, 2009; p.2.

2. Indriana $Y$, Desiningrum DR, Kristiana IF. Religiositas, keberadaan pasangan dan kesejahteraan sosal (social well being) pada lansia binaan PMI cabang Semarang. Jurnal Psikologi Undip. 2011;10:2.

3. Sukartini T, Nursalam. Manfaat senam tera terhadap kebugaran lansia. J. Penelit. Med. Eksakta. 2009;8:2. 
4. Khairani R, Sumiera M. Profil lipid pada penduduk lanjut usia di Jakarta. Universa Medicina. 2005;24:4.

5. Artanti D. Pengaruh pemberian jus buah pare terhadap kadar trigliserida serum tikus wistar jantan yang diberi diet tinggi lemak. Fakultas Kedokteran Diponegoro; 2008.

6. Pranatahadi SB, Suharjana DR, Warsito AA. Pelatihan instruktur senam lansia bugar di desa wijirejo pandak.

7. Prayoga AG, Ningrum AN, Wahyudi A, Arizona DD, Sriwahyuni E, Contesa E. Proposal terapi senam lansia dengan hipertensi di panti werdha darma bakti bagian atas $\mathrm{km} 7$ Palembang. Sekolah tinggi ilmu kesehatan perdhaki charitas; 2012.

8. Ratung Y. Pengaruh tes kesegaran jasmani terhadap kadar trigliserida pada mahasiswa universitas sam ratulangi. Universitas Sam Ratulangi; 2012.

9. Krishna MM, Gopinath V. Effect of aerobic exercise on lipoprofiles of middle aged man. World Journal of Science and Technology. 2011.

10. Anam. Pengaruh Intervensi Diet dan Olahraga dan Indeks Massa Tubuh Kesegaran, hsCRP dan Profil Lipid pada Anak Obesitas [Tesis]. Semarang; Universitas Diponegoro; 2010. 